Tropical Journal of Pharmaceutical Research January 2016; 15 (1): 87-94

ISSN: $1596-5996$ (print); 1596-9827 (electronic)

(C) Pharmacotherapy Group, Faculty of Pharmacy, University of Benin, Benin City, 300001 Nigeria.

All rights reserved.

Available online at http://www.tjpr.org

Original Research Article

http://dx.doi.org/10.4314/tjpr.v15i1.12

\title{
Antidiabetic Activity of Plumeria Alba Linn (Apocynaceae) Root Extract and Fractions in Streptozotocin-Induced Diabetic Rats
}

\author{
Z Tessou Kadébé ${ }^{1}$, Kossi Metowogo², Batomayena Bakoma ${ }^{3 \star}$, S Poevi Lawson- \\ $\mathrm{Evi}^{2}$, Kwashie Eklu-Gadegbeku ${ }^{2}$, Kodjo Aklikokou ${ }^{2}$ and Messanvi Gbeassor ${ }^{3}$ \\ ${ }^{1}$ Graduate Institute of Science and Technology of Abéché (IUSTA), PO Box 130, Abéché, Tchad, ${ }^{2}$ Department of Animal \\ Physiology, Faculty of Sciences, ${ }^{3}$ Department of Pharmacy, Faculty of Health Sciences, University of Lome, Lome, Togo \\ ${ }^{*}$ For correspondence: Email: bbakoma@gmail.com; Tel: +22891000199
}

Received: 12 September 2015

Revised accepted: 15 December 2015

\begin{abstract}
Purpose: To investigate the effect of total hydroalcohol root extract of Plumeria alba (Apocynaceae) and its active fraction on diabetes in rats.

Methods: The effect of total hydroalcohol extract at $250 \mathrm{mg} / \mathrm{kg}$ and different fractions was evaluated on oral glucose tolerance test (OGTT) in mice. The effect of the active fractions on OGTT was measured on a model of diabetic rats (fructose-enriched fat diet and streptozotocin-induced).

Results: The results show that the total extract $(250 \mathrm{mg} / \mathrm{kg})$, ethyl acetate fraction and supernatant fraction (obtained after centrifugation of total extract) at a dose of $100 \mathrm{mg} / \mathrm{kg}$ significantly $(p<0.01)$ reduced hyperglycemia induced by glucose overload in mice. Fructose-enriched fat diet increased blood cholesterol, triglycerides and high density lipoprotein (HDL) levels in hyperlipidemic untreated rats compared to normal control rats. Administration of total extract $(250 \mathrm{mg} / \mathrm{kg} / \mathrm{day})$ and supernatant fraction of $P$. alba $(100 \mathrm{mg} / \mathrm{kg} /$ day) during 14 days significantly reduced lipid parameters (total cholesterol, $p<0.001$; triglycerides, $p<0.01 ; \mathrm{HDL}, p<0.05$ ). Analysis of oxidative stress markers shows that the supernatant fraction and total extract significantly increased serum glutathione level ( $p$ $<0.01)$ but significantly lowered malondialdehyde $(M D A)$ concentration in liver $(p<0.05)$.

Conclusion: These results suggest that the total extract and fractions of $P$. alba exhibit significant antidiabetic and hypolipidemic properties in streptozotocin-induced diabetic animals. The supernatant fraction (which is free of organic solvent) was the most biologically active
\end{abstract}

Keywords: Diabetes, Hyperlipidermia, Plumeria alba, Fructose-enriched fat diet, Oxidative stress markers, Streptozotocin

\footnotetext{
Tropical Journal of Pharmaceutical Research is indexed by Science Citation Index (SciSearch), Scopus, International Pharmaceutical Abstract, Chemical Abstracts, Embase, Index Copernicus, EBSCO, African Index Medicus, JournalSeek, Journal Citation Reports/Science Edition, Directory of Open Access Journals (DOAJ), African Journal Online, Bioline International, Open-J-Gate and Pharmacy Abstracts
}

\section{INTRODUCTION}

Diabetes mellitus (DM) is a chronic metabolic disorder caused by an absolute or relative lack of/or resistance to insulin and is characterized by hyperglycemia in the postprandial and/or fasting state [1]. Presently, it is estimated that 220 million people worldwide have diabetes and this number will increase to 300 million on 2025.
Globally, type-2 diabetes (non-insulin dependent diabetes mellitus) accounts more than ninety percent of all cases of diabetes is caused by a combination of resistance to insulin action and impaired insulin secretion, resulting glucose intolerance [2]. This metabolic disorder characterized by chronic hyperglycemia (fasting blood glucose $\geq 7 \mathrm{mmol} / \mathrm{l}$ ) is known to be the major initiator of micro and macro vascular 
complications in diabetics [3,4]. Therefore, control of postprandial plasma glucose levels is important in the early treatment of diabetes and reducing chronic vascular complications.

Impaired glucose tolerance (IGT) is a risk factor for future diabetes and/or adverse outcomes. It is characterized by a moderate hyperglycemia $2 \mathrm{~h}$ post-load plasma-glucose that results from muscle insulin resistance and impaired insulin secretion [5]. The loss of early insulin secretion in IGT and type 2 diabetes is the result of malfunctioning of the pancreatic B-cells [6]. In the long-term, high blood glucose levels are toxic to B-cells, leading to further deterioration in B-cell function and worsening blood glucose control [7]. About 20 to $50 \%$ of the people with IGT will, within a period of 10 years develop type 2 diabetes, accompanied by increased risk of cardiovascular disease and micro vascular complications [8].

Elevated blood glucose levels have been shown to increase oxidative stresses which are known to induce $\beta$-cell apoptosis [9] and consequently, antioxidant potential of plant secondary metabolites. Hence, compounds with both antihyperglycemic and antioxidative properties would be useful drugs for the control of glycemia and evolution of type 2 diabetes and related cardiovascular complications.

The objective of this study was to develop an alternative non-genetic rat model for type 2 diabetes and to evaluate the anti-diabetic effect of total extract and supernatant fraction of Plumeria alba on this model induced by high fructose diet and intraperitoneal administration of streptozotocin. These rats form a model of experimental diabetes with glucose intolerance, hepatic oxidative stress, hyperlipidemia and high risk of coronary heart diseases.

\section{EXPERIMENTAL}

\section{Plant material and extraction}

$P$. alba root were collected from the garden of the Teaching Hospital Sylvanus Olympio of Lomé, Togo. A specimen was identified by the Laboratory of Botany and Plant Ecology (Faculty of Science/University of Lomé) and retained in the department herbarium under number 8035 . The roots were washed, dried under airconditioning and reduced to powder with electric mill (Thomas Scientific $\left.{ }^{\mathrm{TM}}, 3375-\mathrm{E} 20\right) .800 \mathrm{~g}$ of the powder was cold extracted in ethanol $95 \%$ water mixture $(80: 20)$ for $72 \mathrm{~h}$. The crude extracts were filtered with Whatman paper $\left(\mathrm{N}^{\circ} 1\right)$ and evaporated under vacuum at $45^{\circ} \mathrm{C}$ using a rotary evaporator Büchi R210. The yield of the preparation was $11.34 \%$.

\section{Fractionation of hydro alcoholic extract}

Hydro alcoholic extract of $P$. alba was fractioned using technique of separation by precipitation in cold alcohol. $30 \mathrm{~g}$ of total extract were dissolved in $400 \mathrm{ml}$ of $75 \%$ alcohol. The solution was put in a refrigerator at $4{ }^{\circ} \mathrm{C}$ for $24 \mathrm{~h}$ to allow the precipitate settle at the bottom of the tube. The supernatant was separated from the clot by centrifugation at $2500 \mathrm{~g}$ and then evaporated under vacuum at $45{ }^{\circ} \mathrm{C}$. The pellet from the supernatant was dried at ambient air. The fractions obtained are respectively the supernatant fraction (SF) and the Dregs from supernatant fraction (DS).

Ethyl acetate fraction (EA) was obtained by dissolving $30 \mathrm{~g}$ of total extract in $5 \mathrm{ml}$ of distilled water and then in $400 \mathrm{ml}$ of ethyl acetate. The mixture was refrigerated at $4{ }^{\circ} \mathrm{C}$ for $24 \mathrm{~h}$, treated as above and the supernatant was evaporated to give the ethyl acetate fraction (EA).

These splits have allowed us to have fractions successively named supernatant fraction (SF) with a yield of $73.33 \%$, dregs from supernatant fraction (DS) yield $23.33 \%$, an ethyl acetate fraction (EA) $82.20 \%$.

\section{Animals}

Male Sprague Dawley rats (body weight ranging from 150 to $200 \mathrm{~g}$ ) and ICR mice (body weight ranging from 20 to $30 \mathrm{~g}$ ) were provided from the Animal House of physiology/pharmacology department of the University of Lomé (Togo). Animals were maintained at the standard environmental conditions (temperature of $25 \pm 2$ ${ }^{\circ} \mathrm{C}$ and $12 / 12 \mathrm{~h}$ of light/dark cycle). They were given standard commercial rat chow and water ad libitum. Principles of laboratory animal care as described in the European Community guidelines were followed [10]. This study has the approval of institute's ethical committee on animal experimentation.

\section{Chemicals}

Products used for the pharmacological test were purchased from Sigma (St. Louis, Mo, USA, Richmond, CA, USA). The assay of total cholesterol and triglyceride were made using Labkit Chemelex-SA (Barcelona, Spain). 
Oral glucose tolerance test (OGTT) in normal mice

The effect of total extract and fractions were evaluated on oral glucose tolerance test using 42 mice divided into 6 groups of seven animals each: Group I received distilled water (control group); Group II received total extract (ET) at dose of $250 \mathrm{mg} / \mathrm{kg}$; Groups III received supernatant fraction (SF) at dose of $100 \mathrm{mg} / \mathrm{kg}$; Groups IV received ethyl acetate fraction (EA) at dose of $100 \mathrm{mg} / \mathrm{kg}$ body weight; Group V received the dregs of supernatant fraction (DS) at dose of $100 \mathrm{mg} / \mathrm{kg}$ of body weight; Group VI received glibenclamide (GB) at the dose of 0.6 $\mathrm{mg} / \mathrm{kg}$ body weight.

Thirty minutes $(30 \mathrm{mn}$ ) later, D-glucose solution $(2.0 \mathrm{~g} / \mathrm{kg})$ was given orally to each mouse. Preprandial glucose level was measured; 30,60 , 120 and $180 \mathrm{~min}$ after the glucose loading (postprandial glucose level) blood glucose level was measured with a glucometer (One Touch Ultra).

\section{Determination of anti-diabetic activity}

Before the administration of streptozotocin (STZ), rats were fed for 11 days with an enriched diet (Bacon-Fructose). The mixture lard-Fructose is prepared as follows: Fructose $(6 \mathrm{~g})$ was dissolved in $50 \mathrm{ml}$ distilled water with $1.25 \mathrm{ml}$ of tween $80 \%$. This solution was mixed to $50 \mathrm{ml}$ of melted lard. After fasting for $16 \mathrm{~h}$, streptozotocin (in a cold freshly prepared solution of $0.1 \mathrm{M}$ citrate buffer, $\mathrm{pH}$ 4.5) was administered to rats by intraperitoneal route at $45 \mathrm{mg} / \mathrm{kg}$ on day 12 [8]. Animal were maintained under lard-fructose diet for 3 days after STZ injection and Blood glucose level was measured to evaluate the stability. Only rats with blood glucose level greater than $200 \mathrm{mg} / \mathrm{dl} 72 \mathrm{~h}$ after administration of STZ were selected to constitute the group of diabetic animals.

\section{Animal treatment}

Five groups of 8 rats were established as follows: Group I as normal control (NC) received distilled water for 14 days; Group II diabetic control (DC) received distilled water for 14 days; Group III, IV and $\mathrm{V}$ were treated, respectively, with total extract $(250 \mathrm{mg} / \mathrm{kg})$, supernatant fraction (100 $\mathrm{mg} / \mathrm{kg}$ ) and glibenclamide $(0.6 \mathrm{mg} / \mathrm{kg})$ for 14 days. Blood glucose was measured every 7 days and body weight of animals was measured every two days. At the end of treatment (day 14), rats were anesthetized under ether and blood was collected by retro - orbital sinus. Blood collected was centrifuged at $3000 \mathrm{rpm}$ for 10 minutes. Serum obtained was used for determination of blood urea, creatinine, triglycerides, total cholesterol and HDL cholesterol level using commercial kits. Low density lipoprotein (LDL) was calculated by using Friedewald formula [11].The liver was frozen during $48 \mathrm{~h}$ for evaluation of lipid peroxidation.

\section{Total hemoglobin $(\mathrm{Hb})$ and glycosylated hemoglobin (HbA1c) assays}

The assay is performed by the DCA $2000 \mathrm{HbA} 1 \mathrm{c}$ system. The Ames DCA $2000 \mathrm{HbA1c}$ (Bayer Diagnostics, Elkart, IN, USA) apparatus is a portable analyzer, performing a system based on the inhibition of agglutination of latex particles immunoassay.

\section{Determination of plasma GSH activity}

Sedlak and Lindsay [12] method was used with slight modification. $150 \mu \mathrm{L}$ of Tris $(0.2 \mathrm{M}, \mathrm{pH}=$ 8.2) and $10 \mu \mathrm{L}$ of 5,5 '-dithiobis-2-nitrobenzoic acid (DTNB) $(0.01 \mathrm{M})$ were added to $50 \mu \mathrm{L}$ of serum or GSH. To this mixture, $790 \mu \mathrm{L}$ of absolute methanol was added to reach $1 \mathrm{ml}$. All tubes were tightly closed and homogenized for a half hour. Centrifugation of all tubes was done at $3000 \mathrm{rpm}$ for $15 \mathrm{~min}$ at room temperature. The absorbance was read at $412 \mathrm{~nm}$ after five [5] minutes of incubation.

\section{Lipid peroxidation assay}

Solution of 1 -methyl-2-phenylindole at 10 mMis mixed with the iron chloride at a concentration of $32 \mu \mathrm{M}$ in the proportions of 75: $25(\mathrm{v} / \mathrm{v})$. Acetonitrile was used as solvent of 1 - methyl - 2 - phenylindole and methanol as solvent of the iron chloride. The liver homogenate was prepared grinding $0.5 \mathrm{~g}$ liver in $500 \mu \mathrm{L}$ of buffer $0.1 \mathrm{M}$ Tris $\mathrm{HCl} \mathrm{pH} \mathrm{7.4.} \mathrm{The} \mathrm{reaction} \mathrm{medium}$ contains $650 \mu \mathrm{L}$ of 1 -methyl -2- phenylindole activated $250 \mu \mathrm{L}$ of MDA liver homogenate, 150 $\mu \mathrm{L}$ of the $\mathrm{HCl}$ solution at a concentration of $12 \mathrm{~N}$ and $10 \mu \mathrm{L}$ of the solution of BHT (butylated hydroxy toluene) at a concentration of $0.1 \mathrm{M}$. The incubation of tubes was done at $45^{\circ} \mathrm{C}$ for $1 \mathrm{~h}$. The tubes were then centrifuged at $5000 \mathrm{rpm}$ for $10 \mathrm{~min}$. The absorbance was read at the wavelength of $526 \mathrm{~nm}$. The blank sample was 75 $\%$ acetonitrile, $25 \%$ of iron chloride and $200 \mu \mathrm{L}$ of Tris solution with a pH equal to $7.4[13,14]$.

\section{Statistical analysis}

Data are presented as mean \pm SEM (n). Oneway ANOVA with Dunett's Multiple Comparison post-test was performed to assess differences between groups (Graph PadPrism 5, San Diego, CA). $P<0.05$ were considered statistically significant.

Trop J Pharm Res, January 2016; 15(1): 89 


\section{RESULTS}

\section{Effect of $P$. alba total extract and fractions on oral glucose tolerance (OGT)}

Figure $1(A)$ shows the variation of blood glucose level. At $T_{0}$, the average blood glucose level in the control like treated group was $91.16 \pm 5.75$ $\mathrm{mg} / \mathrm{dl}$. Thirty minutes (30 $\mathrm{min})$ after administration of glucose, blood glucose level in diabetic control mice reached a maximum average value of $293 \pm 17.17 \mathrm{mg} / \mathrm{dl}$ against $197.00 \pm 1.34 \mathrm{mg} / \mathrm{dl}, 182.71 \pm 2.20 \mathrm{mg} / \mathrm{dl}$, $233.85 \pm 4.32 \mathrm{mg} / \mathrm{dl} ; 271.42 \pm 2.10 \mathrm{mg} / \mathrm{dl}$ and $146.85 \pm 2.60 \mathrm{mg} / \mathrm{dl}$ respectively for supernatant fraction $(100 \mathrm{mg} / \mathrm{kg})$, ethyl acetate fraction (100 $\mathrm{mg} / \mathrm{kg}$ ), total extract $(250 \mathrm{mg} / \mathrm{kg}$ ), Dregs from supernatant fraction $(100 \mathrm{mg} / \mathrm{kg})$ and glibenclamide $(0.6 \mathrm{mg} / \mathrm{kg})$ in the treated mice. Figure 1(B) showed that AUC of glucose during OGTT of diabetic group was elevated by $60 \%$ ( $p$ $<0,001)$ when compared with normal control Group. The AUC of glucose tolerance test in treated groups (total extract, fractions and glibenclamide) was significantly $(p<0,001)$ lower than that of diabetic group showing improved glucose tolerance. This reduction was respectively $32.76 \%(p<0.001), 37.64 \%(p<$ $0.001), 20.18 \%(p<0.01) 7.36 \%(p<0.05)$ and $49.88 \%(p<0.001)$ of reduction. Area under the curve (AUC) (Fig 1 B) confirmed this reduction.

\section{Effect of $P$. alba total extract and supernatant fraction on blood glucose}

Table 1 shows the Levels of blood glucose in diabetic rats during the experiment. On day 0 (start of treatment), blood glucose level in normal control rats was $99.12 \pm 1.46 \mathrm{mg} / \mathrm{dl}$ against $432.75 \mathrm{mg} / \mathrm{dl}$ in diabetic controls (Table 1). After two weeks of treatment, animals treated with total extract, supernatant fraction and glibenclamide showed a significant $(p<0.01)$ reduction of blood glucose level respectively $151.50 \pm 3.02 \mathrm{mg} / \mathrm{dll}, 127.25 \pm 2.92$ and $110.62 \pm$ $1.48 \mathrm{mg} / \mathrm{dl}$ against $268.12 \mathrm{mg} / \mathrm{dl}$ in the diabetic controls.

\section{Effect of $P$. alba total extract and supernatant fraction on rat body weight}

Table 2 shows rat body weight variation during the experiment. The average body weight of diabetic control (DC) group was $184.14 \pm 1.5 \mathrm{~g}$ against $168.28 \pm 1.67 \mathrm{~g}$ in normal control (NC)
A
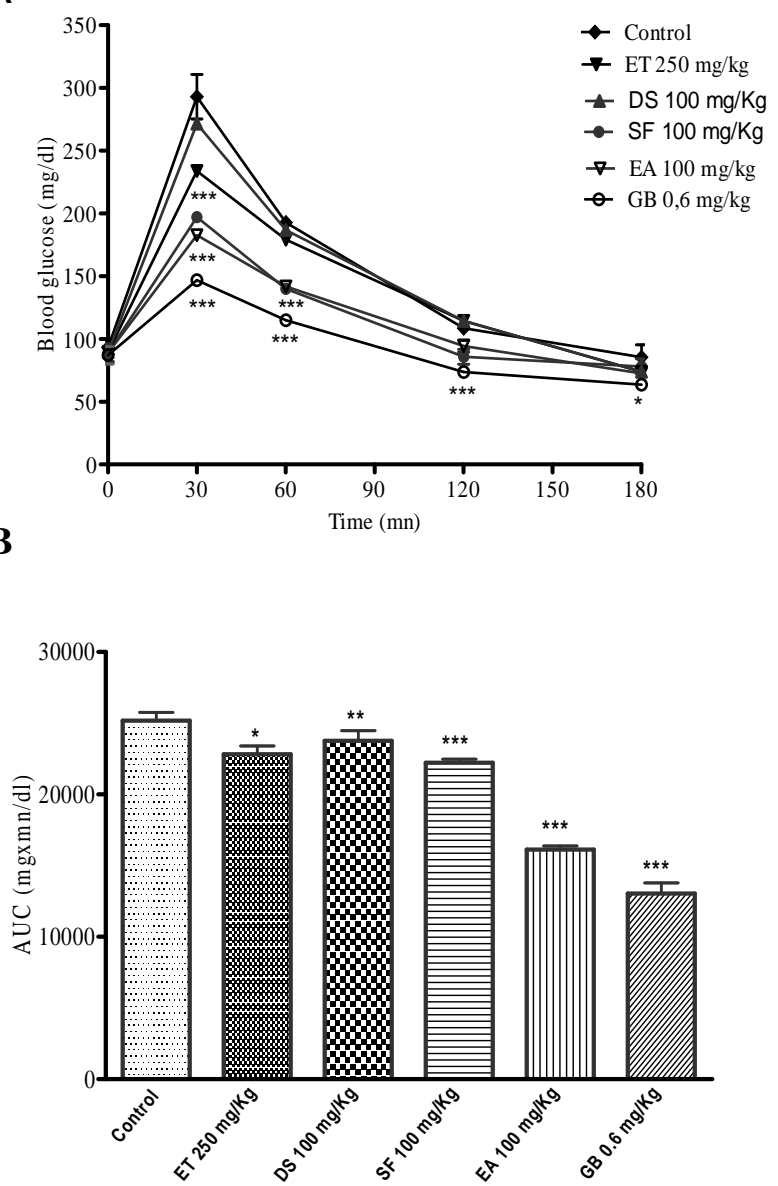

Figure 1: Effect of $P$. alba total extract an fractions on oral glucose tolerance test in normal rats. A: Blood glucose level; B:area under the curve (AUC); Control: received distilled water ; ET $250 \mathrm{mg} / \mathrm{kg}$ : received Total extract at dose of $250 \mathrm{mg} / \mathrm{kg}$ body weight; received; SF100 mg / kg: supernatant fraction at dose of $100 \mathrm{mg} / \mathrm{kg}$ body weight; EA100 mg/kg received ethyl acetate fraction at dose of $100 \mathrm{mg} / \mathrm{kg}$ body weight; DS: received the dregs of supernatant fraction at dose of $100 \mathrm{mg} / \mathrm{kg}$ of body weight; GB received glibenclamide at the dose of $0.6 \mathrm{mg} / \mathrm{kg}$ body weight. Thirty minutes $(30 \mathrm{mn})$ later, glucose solution $(2.0 \mathrm{~g} / \mathrm{kg}$ b.w.) was given orally to each mouse.0, 30, $60,120,180$ min after glucose loading, blood glucose level was measured with a glucometer (One Touch Ultra). Values are expressed as the mean \pm SEM $(n=$ 7). ${ }^{*} p<0.05 ;{ }^{* *} p<0.01 ;{ }^{* * *} p<0.001$ vs control

group at the start of treatment $\left(\mathrm{D}_{0}\right)$. After 2 weeks of treatment $\left(D_{14}\right)$, body weight in normal control group was $178.25 \pm 154.12 \mathrm{~g}$ against $154.14 \pm$ $1.50 \mathrm{~g}$ in diabetic control group. Group treated with total extract, supernatant fraction and glibenclamide showed a significant increase ( $p$ $<0.001$ ) of animals body weight at D14 (respectively $165.12 \pm 1.39 \mathrm{~g}, 166.00 \pm 0.86 \mathrm{~g}$ and $169.14 \pm 1.22 \mathrm{~g})$ compared to diabetic control $(154.42 \pm 1.98 \mathrm{~g})$. 


\section{Effect of $\boldsymbol{P}$. alba total extract and supernatant fraction on rat biochemical parameters}

Diabetic control showed a significant increase in triglycerides and total cholesterol, compared to normal controls. The administration of $P$. alba total extract significantly reduced serum level of TG while increasing HDL-cholesterol level $(p<$ 0.01 ) compared to diabetic controls.

The supernatant fraction $(100 \mathrm{mg} / \mathrm{kg} /$ day) and glibenclamide $(0.6 \mathrm{mg} / \mathrm{kg} /$ day$)$ administered orally reduced significantly $(p<0.01)$ serum level of TG and total cholesterol compared to diabetic controls. There was a significant $(p<0.01)$ increase in creatinine level $(15.78 \pm 0.31)$ and urea level $(47.25 \pm 0.85)$ in untreated diabetic rats compared respectively to normal control rats (10.28 \pm 0.25$)$ and (38.33 \pm 0.98$)$. Blood creatinine and urea level were significantly $(p<$ 0.01 ) reduced in rats treated with the total extract and compared to diabetic control rats (Table 3 ).

Table 1: Effect of $P$. alba total extract supernatant fraction and glibenclamide on the evolution of blood glucose level during the treatment

\begin{tabular}{|c|c|c|c|c|c|}
\hline & \multicolumn{5}{|c|}{ Blood Glucose (mg/dl) } \\
\hline & \multirow[b]{2}{*}{ NC } & \multirow[b]{2}{*}{ DC } & \multicolumn{3}{|c|}{ Dose (mg/kg) } \\
\hline & & & SF 100 & ET 250 & GB 0.6 \\
\hline \multicolumn{6}{|l|}{ JO } \\
\hline J3 & $99.12 \pm 1.46$ & 432.75 $3.58 \# \# \#$ & $434.75 \pm 15.61$ & $453.50 \pm 13.54$ & $448.25 \pm 17.51$ \\
\hline & $99.62 \pm 1.22$ & 423.37士4.35\#\#\# & $398.62 \pm 15.97$ & $406.75 \pm 18.54$ & $391.00 \pm 18.20$ \\
\hline$J 7$ & $100.37 \pm 1.33$ & $357.25 \pm 8.12 \# \# \#$ & $248.12 \pm 11.42^{* \star *}$ & $282.50 \pm 9.98^{* * *}$ & $179.37 \pm 4.03^{* * *}$ \\
\hline J14 & $102.50 \pm 0.94$ & $268.12 \pm 3.34 \# \# \#$ & $127.25 \pm 2.92^{\star \star \star}$ & $151.50 \pm 3.02^{\star \star \star}$ & $110.62 \pm 1.48^{\star \star \star}$ \\
\hline
\end{tabular}

Table 2: Effect of total extract and supernatant fraction obtained after centrifugation of total extract of $P$. alba on body weight

\begin{tabular}{|c|c|c|c|c|c|}
\hline \multicolumn{2}{|r|}{ NC } & DC & SF $100 \mathrm{mg} / \mathrm{Kg}$ & ET 250 mg/Kg & GB $0.6 \mathrm{mg} / \mathrm{Kg}$ \\
\hline$\overline{D_{0}}$ & $172.85 \pm 1.20$ & $184.14 \pm 1.50^{\# \# \#}$ & $183.14 \pm 1.26$ & $181.28 \pm 1.40$ & $181.14 \pm 1.37$ \\
\hline $\mathbf{D}_{7}$ & $175.28 \pm 1.40$ & $169.71 \pm 1.52$ & $175.14 \pm 1.40^{*}$ & $172.85 \pm 1.05$ & $176.28 \pm 1.06^{* *}$ \\
\hline $\mathrm{D}_{14}$ & $178.28 \pm 1.20$ & $154.42 \pm 1.98^{\# \# \#}$ & $166.00 \pm 0.86^{\star * *}$ & $165.00 \pm 1.39^{\star * *}$ & $169.14 \pm 1.22^{* \star \star}$ \\
\hline
\end{tabular}

NC: normal control received distilled water for 14 days; DC : diabetic control received distilled water for 14 days; ET250, SF100 and GB0.6 were diabetic animals treated respectively with total extract $(250 \mathrm{mg} / \mathrm{kg})$, supernatant fraction ( $100 \mathrm{mg} / \mathrm{kg}$ ) and glibenclamide $(0.6 \mathrm{mg} / \mathrm{kg})$ for 14 day. Values are expressed as the mean \pm SEM $(\mathrm{n}$ $=8) .{ }^{\# \# \#} p<0.05$ vs control; ${ }^{* * *} p<0.001$ vs Diabetic control

Table 3: Effect of $P$. alba total extract and supernatant fraction and glibenclamide on biochemical parameters

\begin{tabular}{|c|c|c|c|c|c|}
\hline Parameter & NC & DC & ET250 & SF 100 & GB 0,6 \\
\hline $\mathrm{TG}(\mathrm{mg} / \mathrm{dl})$ & $29.83 \pm 1.90$ & $74.17 \pm 4.01^{\# \# \#}$ & $54.67 \pm 5.60^{*}$ & $47.00 \pm 6.48^{\star *}$ & $36.70 \pm 20^{\star \star *}$ \\
\hline $\mathrm{Ch}(\mathrm{mg} / \mathrm{dl})$ & $59.67 \pm 3.28$ & $68.33 \pm 3.62^{\# \#}$ & $57.95 \pm 3.20$ & $63.6 \pm 3.40^{*}$ & $64.86 \pm 4.62^{*}$ \\
\hline HDL-C (mg/dl) & $42.50 \pm 1.67$ & $31.20 \pm 2.2^{\# \#}$ & $49.33 \pm 4.60^{*}$ & $51.67 \pm 3.36^{\star *}$ & $54.56 \pm 3.09^{* *}$ \\
\hline LDL-C (mg/dl) & $11.20 \pm 1.10$ & $22.29 \pm 3.40^{\# \#}$ & $2.31 \pm 1.60^{\star * *}$ & $2.53 \pm 1.50^{\star \star *}$ & $2.96 \pm 1.40^{\star * *}$ \\
\hline Urée(mg/dl) & $38.33 \pm 0.98$ & $47.25 \pm 0.85^{\# \#}$ & $30.33 \pm 0.98^{*}$ & $29.16 \pm 0.70^{\star}$ & $27.00 \pm 0.51^{\star *}$ \\
\hline Créat (mg/dl) & $10.28 \pm 0.25$ & $15.78 \pm 0.31^{\# \#}$ & $9.28 \pm 0.25^{\star \star}$ & $7.80 \pm 0.19^{\star \star \star}$ & $8.46 \pm 0.26^{\star \star}$ \\
\hline
\end{tabular}

NC: normal control received distilled water for 14 days; DC : diabetic control received distilled water for 14 days; ET250, SF100 and GB0.6 were diabetic animals treated respectively with total extract $(250 \mathrm{mg} / \mathrm{kg})$, supernatant fraction $(100 \mathrm{mg} / \mathrm{kg})$ and glibenclamide $(0.6 \mathrm{mg} / \mathrm{kg})$ for 14 day. Values are expressed as the mean \pm SEM $(n=$ 8). ${ }^{\# \# \# ~} p<0.05$ vs control; ${ }^{* * *} p<0.001$ vs. Diabetic control 
Effect of $P$. alba total extract and supernatant fraction obtained after centrifugation of total extract on total hemoglobin and HbA1c of diabetic rats

Total hemoglobin in normal control group was $12.80 \pm 0.40 \mathrm{mg} / \mathrm{dl}$ against $9.53 \pm 0.14 \mathrm{mg} / \mathrm{dl}$ in diabetic control. In animals treated with total extract, supernatant and glibenclamide, $\mathrm{HbA} 1 \mathrm{c}$ values were respectively $10.65 \pm 0.04 \mathrm{mg} / \mathrm{dl}$, $10.60 \pm 0.04 \mathrm{mg} / \mathrm{dl}$ and $1161 \pm 0.26 \mathrm{mg} / \mathrm{dl}$. There was a significant reduction $(p<0.01)$ of the glycated hemoglobin, to $12.33 \pm 0.23 \%$ for diabetic control against $10.20 \pm 0.02 \%, 10.84 \pm$ $0.08 \%$ and $7.18 \pm 0.25 \%$ respectively for extract, the supernatant and glibenclamide treated group (Table 4).
Effect of $P$. alba total extract and supernatant fraction on hepatic lipid peroxidation and serum GSH levels

The concentration of MDA in diabetic control $(1.53 \pm 0.01 \mathrm{nM} / \mathrm{mg})$ was significantly $(p<0.01)$ higher than that of normal control group (0.96 \pm $0.02 \mathrm{nM} / \mathrm{mg}$ ). Administration of total extract (250 $\mathrm{mg} / \mathrm{kg} /$ day $)$ and the supernatant $(100 \mathrm{mg} / \mathrm{kg})$ daily for 14 days reduced the MDA concentration respectively to $1.4 \pm 0.01 \mathrm{nM} / \mathrm{mg}$ and $1.21 \pm 0.09 \mathrm{nM} / \mathrm{mg}(p<0.05)$,. Administration of total extract $(250 \mathrm{mg} / \mathrm{kg}$ ) or supernatant $(100 \mathrm{mg} / \mathrm{kg})$ induce significant increase $(p<0.001)$ of GSH level in serum compared to untreated diabetic animals (Table $5)$.

Table 4: Effect of $P$. alba total extract supernatant fraction and glibenclamide on haemoglobin $(\mathrm{Hb})$ and glycosylated haemoglobin $(\mathrm{HbA} 1 \mathrm{c})$

\begin{tabular}{lccccc}
\hline Parameter & NC & DC & ET 250 & SF 100 & GB 0.6 \\
\hline $\mathrm{Hb}(\mathrm{g} / \mathrm{dl})$ & $12.80 \pm 0.40$ & $9.53 \pm 0.14$ & $10.60 \pm 0.04^{\star}$ & $10.65 \pm 0.04^{*}$ & $11.61 \pm$ \\
$\mathrm{HbA} 1 \mathrm{c}(\% \mathrm{Hb})$ & $5.80 \pm 0.32$ & $12.33 \pm 0.23^{\# \# \#}$ & $10.20 \pm 0.02^{\star \star}$ & $10.84 \pm 0.08^{\star}$ & $7.18 \pm 0.25^{\star \star \star}$
\end{tabular}

NC: normal control received distilled water for 14 days; DC : diabetic control received distilled water for 14 days; ET250, SF100 and GB0.6 were diabetic animals treated respectively with total extract $(250 \mathrm{mg} / \mathrm{kg})$, supernatant fraction $(100 \mathrm{mg} / \mathrm{kg})$ and glibenclamide $(0.6 \mathrm{mg} / \mathrm{kg})$ for 14 day. Values are expressed as the mean \pm SEM $(n=8)$. $\#$ \#\#\# 0.05 vs control; ${ }^{* \star *} p<0.001$ vs. Diabetic control

Table 5: Effect of $P$. alba total extract supernatant fraction and glibenclamide on MDA and liver glutathione in streptozotocin-induced diabetic rats

\begin{tabular}{lccccc}
\hline Parameter & NC & DC & ET 250 & SF100 & GB 0.6 \\
\hline MDA (nM/mg) & $0.96 \pm 0.02$ & $1.53 \pm 0.01^{\# \#}$ & $1.4 \pm 0.01^{*}$ & $1.21 \pm 0.09^{\star *}$ & $0.97 \pm 0.01^{\star *}$ \\
GSH ( $\mu \mathrm{mol} / \mathrm{mg}$.prot) & $34.50 \pm 0.73$ & $19.87 \pm 1.002^{\# \#}$ & $26.87 \pm 0.76^{\star *}$ & $31.5 \pm 0.70^{\star * *}$ & $36.12 \pm 0.895^{\star * \star}$
\end{tabular}

NC: normal control received distilled water for 14 days; DC : diabetic control received distilled water for 14 days; ET250, SF100 and GB0.6 were diabetic animals treated respectively with total extract $(250 \mathrm{mg} / \mathrm{kg}$ ), supernatant fraction $(100 \mathrm{mg} / \mathrm{kg}$ ) and glibenclamide $(0.6 \mathrm{mg} / \mathrm{kg})$ for 14 day. Values are expressed as the mean \pm SEM $(\mathrm{n}$ = 8). ${ }^{\# \# \# ~} p<0.05$ vs control; ${ }^{* * *} p<0.001$ vs. Diabetic control

\section{DISCUSSION}

The present study focuses on the antidiabetic activity of $P$. alba. The effect of hydroalcohol total extract and fractions on disturbances metabolic related diabetic condition such as: dyslipidemia dominated by hypertriglyceridemia, depressed HDL-cholesterol; insulin resistance characterized by accumulation of intra-abdominal fat and glucose intolerance.

The hypoglycemic effect of the total extract, supernatant fractions (SF), ethyl acetate (EA), and the dregs of supernatant was evaluated on normal mouse hyperglycemia caused by OGTT. The results of this test showed that the total extract, supernatant and ethyl acetate fraction have significantly reduced hyperglycemia in 30 min. A comparison of different fractions activities showed that mice treated with ethyl acetate fractions and supernatant fraction at a dose of $100 \mathrm{mg} / \mathrm{kg}$ had the highest hypoglycemic effect. Our previous studies performed on the hydroalcoholic total extract showed a decrease in basal glucose levels in normal rats [14]. This indicates that hypoglycemic activity of the plant is mediated by increased peripheral glucose metabolism or by a direct or indirect stimulation of insulin secretion. This hypoglycemic activity would be comparable to that of the reference drug used (glibenclamide $0.6 \mathrm{mg} / \mathrm{kg}$ ). It is an oral antidiabetic agent which acts sulfonamide stimulating insulin secretion by binding a specific receptor Sulfonyl Urea Receptor (ON) present on 
the membrane of pancreatic beta cells. Sulfonamides thus stimulate the release of insulin already synthesized.

In this study, STZ was used to induce diabetes. It selectively destroys the insulin secreting pancreatic cells, leaving the less active cells and thus resulting in diabetic state [15]. STZ-induced diabetes is characterized by severe weight loss which was observed in the present study. The reduction in body weight may be attributed to insulin depletion provoking a loss of adipose tissues. The loss of weight in diabetic rats might also be the result of degradation of structural proteins due to unavailability of carbohydrate as energy source [16]. For this reason, weight reduction is being used as a marker of diabetes mellitus induced by STZ [17]. In the present study, supernatant fraction (SF) was chosen among all active fractions for STZ induced diabetes because of his similarity to traditional preparation with no toxic solvent. Then, oral administration of total extract and supernatant of $P$. alba to STZ-induced diabetic rats caused significant improvement in the body weight gain. This may be due to the effect of total extract and supernatant fraction of $P$. alba on glucose metabolism.

In the present study, an increase of blood glucose level in diabetic rats confirmed the induction of diabetes by STZ. The fundamental mechanism underlying hyperglycemia in diabetes involves the overproduction of glucose by excessive hepatic glycogenolysis, gluconeogenesis and decreased utilization by the tissues [18]. A significant decrease of blood glucose level in total extract and supernatant of $P$. alba treated diabetic rats compared to diabetic control rats was observed. This could be due to the regeneration of existing pancreatic beta cells and enhanced transport of glucose to the peripheral tissues by hydro alcoholic extract and supernatant of $P$. alba.

A significant decrease in the level of total hemoglobin and significant increase in the level of glycosylated hemoglobin observed in STZ induced diabetic rats might be due to the increased formation of glycosylated hemoglobin. Glycosylated hemoglobin was found to increase in uncontrolled diabetes and the increase is directly proportional to the fasting blood glucose level for about 3 months [19]. During diabetes, the excess glucose present in the blood reacts with hemoglobin to form glycosylated hemoglobin [20]. Therefore, total hemoglobin level is decreased in diabetic rats. The rate of glycation is directly proportional to the concentration of blood glucose [20]. The level of glycosylated hemoglobin has been shown to provide an index of blood glucose concentration [22]. The decreased level of glycosylated hemoglobin and increased level of total hemoglobin observed in hydro alcoholic extract and supernatant of $P$. alba administered diabetic rats may be due to the reduction of blood glucose level.

Lipid profile is of crucial importance in the diagnosis and treatment of several cardiovascular diseases and control of diabetic patients [23]. Studies have reported that cardiovascular complications associated with diabetes are due to disturbances of lipid metabolism [24]. The results of this study showed significant increase of lipid parameters in STZ induced diabetic animal such as: total cholesterol, TG and LDL-cholesterol, all this combined with a decrease in HDL-cholesterol. The administration of total extract and the supernatant fraction of $P$. alba led to a significant improvement in lipid profile. A low concentration of HDL-cholesterol can be regarded as an additional risk factor and then a high concentration of HDL-cholesterol is a protective factor. It was proposed to use the ratios (total cholesterol/HDL-cholesterol) or (LDLcholesterol/HDL-cholesterol) as an indicator of cardiovascular risk. Administration of total extract and supernatant of $P$. alba increased significantly HDL-cholesterol. $P$. alba is endowed with hypoglycemic and hypolipidemic properties and can therefore be used in the treatment of cardiovascular complications associated with diabetes.

Chronic hyperglycemia in diabetes leads to oxidative stress characterized by an imbalance between the production of free radical species, peroxides and their removal by enzymatic antioxidant defenses and nonenzymatic cellular. It is reported that the production of ROS and lipid peroxidation are increased in diabetic patients and that oxidative stress is responsible for the pathophysiology of diabetes [23], especially, that associated with antioxidant treatment showed significant improvement and prevention against cardiovascular complications [25].

In this study, lipid peroxidation was evaluated in the liver by measuring the level of MDA (malondialdehyde) marker of peroxidation regarding the evaluation of antioxidant defense mechanisms by the glutathione peroxidase (GSH) in serum. The results showed a significant high MDA levels in STZ diabetic animals with reduction of antioxidant defenses (glutathione decreased). Our results agree with those reported by some authors [9]. The increase of MDA rate indicates increased lipid peroxidation 
and the degree of damage to these organs. GSH depletion may mean oxidation by free radicals oxidized GSSG. Treatment of the diabetic rats with $P$. alba extract not only reduced the formation of MDA in the liver but also positively changed GSH.

\section{CONCLUSION}

Findings from this study reveal that the total extract and supernatant fraction of the total extract possess antidiabetic and hypolipidemic activities which can potentially be developed for the management of diabetes. The findings also lend credence for the use of this plant in the traditional treatment of diabetes mellitus in Togo.

\section{ACKNOWLEDGEMENT}

The authors thank French Cooperation Service (SCAC) for a fellowship granted to Kadebe Zoua for PhD studies in Department of Animal Physiology, University of Lomé, Lome, Togo.

\section{REFERENCES}

1. Leila Z, Eliandra D, Luisa $H$, Anildo C, Moacir G, Bruno $S$, Fatima $R$, Mena $S$. Effect of crude extract and fractions from Vitex megapotamica leaves on hyperglycemia in alloxan-diabetic rats. $J$ Ethnopharmacol 2007; 109: 151-155

2. Li Y, Wen S, Kota B, Peng G, Li G. Punica granatum flower extract, a potent alpha-glucosidase inhibitor, improves postprandial hyperglycemia in Zucker diabetic fatty rats. J. Ethnopharmacol 2005; 99: 239-244.

3. Sheetz KG. Molecular understanding of hyperglycemia's adverse effects for diabetic complications. J A. Med. Assoc 2002; 288: 2579-2588.

4. Di Carli M, Janisse J., Grunberger G, Ager J. Role of chronic hyperglycemia in the pathogenesis of coronary microvascular dysfunction in diabetes. J Am Coll. Cardiol 2003; 41: 1387-1393.

5. WHO/DIF, World Health Organization/International Diabetes Federation. Definition and diagnosis of diabetes mellitus and intermediate hyperglycemia: report of a WHO/IDF. 2006

6. Unwin N, Shaw J, Zimmet P, Alberti K. Impaired glucose tolerance and impaired fasting glycaemia: the current status on definition and intervention. Diab Med 2002; 19:708-723.

7. Steppel J, Horton S. Beta-cell failure in the pathogenesis of type 2 diabetes mellitus. Cur Diab Rep 2004; 4: 169175.

8. Nathan M, Mayer D, De Fronzo A, Heine J, Henry R, Pratley $R$, Zinman $B$. Impaired fasting glucose and impaired glucose tolerance: implications for care. Diab Car. 2007; 30: 753-759.
9. Brownlee M. A radical explanation for glucose-induced beta-cell dysfunction. J Clin Inv 2003; 112: 1788-1790.

10. Official Journal of European Union L197 2007; vol. 50, July

11. Friedewald T, Fredrickson S, Levy J. Estimation of concentration of low density lipoprotein cholesterol in plasma without use of the preparation ultracentrifuge. $J$ Clin Chem 1972; 18: 449.

12. Sedlak J, Lindsay H. Anal Biochem 1968; 25:192-205.

13. Patlolla K, Barnes C, Yedjou C, Veloma B, Tchunwou P. Oxidative stress, DNA damage and antioxidant enzyme activity induced by hexavalent chromium in SpragueDawley rats. Environ Toxicol 2009; 24: 66-73.

14. Kadebe Z, Bakoma B., Metowogo K, Lawson-Evi P, EkluGadegbeku K, Aklikokou K, Gbeassor Messanvi. Effects of Plumeria alba Roots Hydro Alcoholic Extract on some Parameters of Type 2 Diabetes. Res J Med Plant 2014; 8: $140-148$

15. Szkudelski T. The mechanism of alloxan and streptozotocin action in $B$ cells of the rat pancreas. Physiol. Res. 2001; 50: 537-546.

16. Pepato T., Migliorini H, Goldberg A, Kettelhut C. Role of different proteolytic pathways in degradation of muscle protein from streptozotocin-diabetic rats. Am J Physiol 1996; 271: E340-347.

17. Ghosh R, Mukherjee B, Chatterjee M. A novel effect of selenium on streptozotocin-induced diabetic mice. Diabetes Res 1994; 25: 165-171.

18. Yamamoto $H$, Uchigata $Y$, Okamoto $H$. Streptozotocin and alloxan induce DNA strand breaks and poly (ADPribose) synthetase in pancreatic islets. Nature 1981; 294: 284-286.

19. Sen S, Kar M, Roy A, Chakraborti A. Effect of nonenzymatic glycation on functional and structural properties of hemoglobin. Biophys. Chem 2005; 113: 289-298.

20. Kumar A, Haseeb A, Suryanarayana $P$, Ehtesham $N$, Reddy $B$. Elevated expression of alphaA- and alphaBcrystallins in streptozotocin-induced diabetic rat. Arch Biochem Biophys 2005; 444: 77-83.

21. Sheela C, Augusti K. Antidiabetic effects of S-allyl cysteine sulphoxide isolated from garlic allium sativum Linn. Ind J Exp Biol 1992; 30: 523-526.

22. Haller M, Stalvey M, Silverstein J. Pedictors of control of diabetes: monitoring may be the key. J Pediatr 2004; 144: 660-661.

23. Akuyam S, Isah H, Ogala W. Evaluation of serum lipid profile of under-five Nigerian Children. Ann Afr Med 2007; 3: 119-123.

24. Qi X-Y, CW, Zhang Xie B. Magrocides extract from Siratia Grosveuori scavenges free radicals in vitro acid lowers oxidative stress serum glucose and lipid levels in aloxan induced diabetic mice. Nutr Res 2008; 28: 278284.

25. Palsamy $P$, Subramanian S. Resveratrol, a natural phytoalexin, normalizes hyperglycemia in STZnicotinamide induced experimental diabetic rats. Biomed Pharmacother 2008; 62: 598-605.

Trop J Pharm Res, January 2016; 15(1): 94 
Kadebe et al 